\title{
CONVERSION OF BIOLOGICAL TREATMENT PLANT SLUDGE TO ORGANIC FERTILIZER FOR APPLICATIONS IN ORGANIC FARMING
}

\section{Agampodi Sunil Shanta Mendis ${ }^{1,2}$, Shashiprabha Punyakantha Dunuweera ${ }^{1,2}$, Shanta Walpalage ${ }^{3}$ and Rajapakse Mudiyanselage Gamini Rajapakse ${ }^{1,2, *}$}

${ }^{1}$ Department of Chemistry, University of Peradeniya, Peradeniya 20400, Sri Lanka

2 Postgraduate Institute of Science, University of Peradeniya, Peradeniya 20400, Sri Lanka

${ }^{3}$ Department of Chemical and Process Engineering, University of Moratuwa, Katubedda, Sri Lanka

Article Info:

Received:

3 April 2019

Revised:

9 June 2019

Accepted:

20 December 2019

Available online:

10 February 2020

Keywords:

Natural rubber glove dipping industry

Effluent Treatment

Biological treatment plant sludge

Organic fertilizer

Heavy metal analyses

Nutritional value analysis

\begin{abstract}
Conversion of the sludge generated in the biological treatment plants of glove dipping industries of Sri Lanka to a valuable organic fertilizer after removing toxic metal ions such as heavy metals and excess $\mathrm{Zn}$ and $\mathrm{Al}$ present in the sludge to allowable limits is described. In order to do so, the raw materials used were analysed for these species and for their nutritional values. Removal of metal ions by different acids such as $\mathrm{HNO}_{3}$ and acetic acid digestion processes are revealed and the results are compared. Dilution of the metal ion-removed sludge with other raw materials used in organic fertilizer production to enable maintain right $\mathrm{C}: \mathrm{N}$ ratio and the use of these materials in the fertilizer production process used are presented. Application of the fertilizer to soils of fruit and vegetable plantations and measurement of $\mathrm{Zn}, \mathrm{Al}$ and heavy metals in the soil and plant parts and their crops as a function of time is also described. The quality of vegetables and fruits produced by applying this new fertilizer is compared with those obtained in the open market. It has been shown that the former contains no or much less than maximum allowable limits of heavy metals or toxic species when compared to those grown using other organic fertilizers. This study is useful for industrial biological treatment plant sludge management by converting it to a useful product.
\end{abstract}

\section{INTRODUCTION}

Sri Lanka has been placed one of the top-class glove manufactures of the world contributing to more than $5 \%$ of global demand (Zheljazkov and Nielson,1994). The main process used in the rubber glove manufacturing industry is called dipping. Dipping industry uses a preserved concentrated natural rubber. The dry rubber content in latex is approximately $60 \%$ and the ammonia content varies from $0.2 \%$ to $0.7 \%$ on latex by weight (Kerdtongmee et al., 2014). A latex compound is prepared by adding chemicals to the latex as a colloidal solution, dispersion or as an emulsion. The additives include fatty acid soap, zinc oxide, accelerator chemicals (zinc dibutyldithiocarbamate ZDBE), alkylated phenols and inorganic pigments. Dipping process begins with cleaning the porcelain formers and finishes with stripping of the gloves from the formers. Technology adopted for glove manufacturing is well established and widely used by latex glove manufacturers, throughout the globe, particularly in Sri Lanka. However, environmental consideration has not yet been fully incorporated in the design of the dipping process which result- ing in significant environmental concerns and problems (Blackley, 1997).

In rubber glove manufacturing, there are two main sources of effluent; namely, latex compounding waste and leaching tank discharge. Latex compounding waste contains un-coagulated latex and chemical sludge (Devaraj et al., 2017). In the manufacturing process, leaching with water is used to remove water-soluble substances coated on the newly-formed gloves. On some of the lines, a post-leaching has been incorporated as it helps to further reduce the water-extractable protein on the surface of the gloves. Latex compounding effluent is treated using a flocculent to separate out latex particles from the effluent. The latex coagula thus obtained is an excellent source of fuel energy and is used as a raw material to obtain energy for the cement industry (Naqi and Jang, 2019). Leaching tank effluent, which does not usually contain latex particles, can be discharged directly into the holding tank, bypassing the rubber trap. The wastewater contains excess zinc and aluminium where zinc comes from the additives used and aluminium from the alum used as flocculent. Rubber products 
also use various colouring agents and pigments which may contain heavy metals. Finally, the wastewater is treated in the microbial biological treatment plants. As of now, there is no reliable technology for disposal of the sludge generated at these biological treatment plants.

As such, a reliable method to dispose this sludge without a significant adverse effect to the environment is essential. Hence, this study was carried out to convert the biological treatment plant sludge (BTPS) that contains aqueous dispersion of dead bacteria from rubber processing plants to a valuable organic fertilizer. In order to accomplish this goal, BTPS of the Natural Rubber Processing Plants in Sri Lanka (NRPP of SL) which has $2 \%$ Total Dispersed Solids (TDS), were collected in large scale, to meet with the requirement of $1800 \mathrm{~kg}$ of dry sludge. Major requirement, in this case, is the analysis to be done for (i) available metal ions such as $\mathrm{Zn}^{2+}, \mathrm{Al}^{3+}$, and heavy metal ions which have been contaminated from various dyes and pigments used and (ii) nutritional value, in terms of $\mathrm{C}, \mathrm{N}, \mathrm{P}$ and $\mathrm{K}$ contents and $\mathrm{C}: \mathrm{N}$ ratio. The metal ions, if present in excess, are to be removed by extraction, down to below the maximum allowable limits and the $\mathrm{C}: \mathrm{N}$ ratio is to be adjusted to required ranges using other raw materials used in organic fertilizer manufacturing. This was done first by the traditional leaching method, using nitric acid as the leaching agent, where the supernatant solution of the sludge then contains nitrate anion. The removal of nitrate from water requires adsorptive methods since nitrates cannot be easily precipitated out (Turhanen et al., 2015). Ion-exchange (Cummins 2019) and reverse osmosis (Pangarkar et al., 2011) are other possibilities but these techniques are expensive. In order to circumvent this problem and to make the problem advantageous to the industry, we used acetic acid to remove these contaminants (Albers et al., 2011). This was prompted due to several reasons: (i) just like most metal nitrates most of the metal acetates including lead acetate is soluble in water (solubility of lead acetate in water, at $20^{\circ} \mathrm{C}$ is $0.61 \mathrm{~mol} \mathrm{dm}^{-3}$ ), (ii) acetic acid is a commonly used acid in glove manufacturing industries and it can be used as a food to bacteria present in the biological treatment plant thus preventing its environmental contamination, (iii) in the acidic medium prevailing in acetic acid treated wastewater, aluminium triacetate is preferentially formed when compared to Aluminium triacetate is highly soluble in water and hence aluminium present in waste sludge can be totally extracted with acetic acid (v) zinc is the next most abundant contaminant next to aluminium in the sludge and is highly soluble in acetic acid [solubility of zinc acetate in water, at $20{ }^{\circ} \mathrm{C}$, is $2.34 \mathrm{~mol} \mathrm{dm}^{-3}$ ] and (iv) both nitrate and acetate are hard Lewis bases and, according to the Pearson's Hard and Soft Acid Base Principle, hard Lewis bases prefer hard Lewis acids. Both these anions prefer hard Lewis acids such as $\mathrm{H}^{+}, \mathrm{Li}^{+}, \mathrm{Na}^{+}, \mathrm{K}^{+}, \mathrm{Be}^{2+}, \mathrm{Mg}^{2+}, \mathrm{Ca}^{2+}, \mathrm{Sr}^{2+}, \mathrm{Sc}^{3+}, \mathrm{Ti}^{4+}, \mathrm{Zr}^{4+}$, $\mathrm{Cr}^{3+}, \mathrm{Al}^{3+}, \mathrm{Ga}^{3+}, \mathrm{La}^{3+}, \mathrm{Gd}^{3+}, \mathrm{Co}^{3+}$ and $\mathrm{Fe}^{3+}$ (LoPachin, 2011). As such, acetate ion works equally well as nitrate ion in solubilizing these cations. Having ensured that the biological treatment plant sludge is within acceptable levels of toxic components, the purified sludge was used as a raw material to produce organic fertilizer.

Production of compost from agricultural and industrial wastes, and municipal by-products is an important means of recovering organic matter and an important method of sludge disposal (Franke-Whittle and Insam, 2012). Compost is applied to cropland to maintain and improve soil structure and plant nutrition. However, the presence of heavy metals in composts is the main cause of adverse effects on animal and human health (Singh et al., 2011). Excess zinc and aluminium are also harmful to plants. Therefore, an accurate and quantitative analysis of the contents of heavy metals in composts is of primary importance for the routine monitoring and risk assessment and regulation of the environment (Smith, 2019). Elemental analysis of a compost sample requires that the organic fraction of the sample be destroyed; leaving the heavy metals either in solution or in a form that is readily dissolved. The approaches for destroying organic material and dissolving heavy metals fall into two groups: wet digestion by acid mixtures prior to elemental analysis and dry-ashing followed by acid dissolution of the ash (Enders and Lehmann, 2019). Various methods have been presented for digesting plant tissues and soil samples for metal analysis (Hseu et al., 2002). However, composts have very different physical, chemical and biological properties to those of soils and plants and hence dedicated technologies are required for compost analyses (Palanivell, 2013). Gorsuch discovered that methods of digestion that, involves mixtures of nitric, sulphuric or perchloric acids, were satisfactory for digesting mineral elements in organic and biological materials (Gorsuch, 1959). Rodushkin used two digestion methods, including open-vessel digestion with concentrated nitric acid and microwave digestion with a mixture of concentrated nitric acid and hydrogen peroxide, to analyse heavy metals in cereal and coniferous tree samples by ICP-AES (Rodushkin et al., 2004). They found that both procedures supported the fast preparation of numerous samples.

Some standard reference materials, similar to a compost matrix, have been used to elucidate the recovery of heavy metals by different digestion methods (Wheal et al., 2011). However, little attention has been paid to samples of popularly used composts. Therefore, in this research, we developed an appropriate digestion method for determining the heavy metals in the various composts and foods and the results obtained by different extraction methods are compared. We also reveal here the way the compost formulations were manufactured and their application to soils in selected vegetable and farmlands, analysis of the heavy metals and nutritional value of the raw materials, fertilizer formulations, soils and in vegetables and fruits grown using these fertilizer formulations (Jara-Samaniego, 2017).

\section{EXPERIMENTAL}

\subsection{Materials and instruments}

BTPS which has $2 \%$ TDS in selected NRPP of SL were collected in large quantities to meet with requirements. Other raw materials such as cow dung, chicken manure and goat manure were collected from the Western Province Farmlands and dry leaves of plants were collected from those accumulated in Katunayake BOI Zone of Sri Lanka. Raw materials were piled to prepare organic ferti- 
lizer. Dilina Organic Agro, SKR Watta, Vilattawa Road, Vellarawa, Sri Lanka, was selected as the agricultural field. The vegetable plant cultivations chosen were bitter guard and snake guard and the fruit cultivation chosen was their papaya plantation. All chemicals used in analytical procedures were of the highest available purity purchased from Sigma-Aldrich and were used without further purification.

\subsection{Extraction Methods}

\subsubsection{Extraction of metal ions using conc. $\mathrm{HNO}_{3}$ and analysis}

This approach was a partly modified form of that of Zheljazkov et al, where 1.00 of sample was placed in a $250.0 \mathrm{~mL}$ digestion tube and $10.00 \mathrm{~mL}$ of concentrated $\mathrm{HNO}_{3}$ was added (Zheljazkov et al., 2010). The sample was heated for $45 \mathrm{~min}$., at $90^{\circ} \mathrm{C}$, and then the temperature was increased to $150{ }^{\circ} \mathrm{C}$, at which the sample was boiled for 8 h, until a clear solution was obtained. Concentrated $\mathrm{HNO}_{3}$ was added to the sample to replenish evaporation losses (5.00 $\mathrm{mL}$ was added three times) and digestion occurred until the volume was reduced to about $1.00 \mathrm{~mL}$. The interior walls of the tube were washed down with a little amount of distilled water and the tube was swirled throughout the digestion to keep the wall clean and prevent the loss of the sample. After cooling, $5.00 \mathrm{~mL}$ of $1 \% \mathrm{HNO}_{3}$ was added to the sample. The solution was filtered with Whatman No. 42 filter paper followed by Millipore filter paper of pore size $<0.45 \mathrm{pm}$. It was then transferred quantitatively to a $25.00 \mathrm{~mL}$ volumetric flask by adding distilled water. The solution obtained was termed BTPSF- $\mathrm{HNO}_{3}-1$ which was subjected to Inductively Coupled Plasma Atomic Emission Spectroscopic (ICP-AE) analysis. The precipitate was again subjected to the above treatments and the second filtrate thus obtained was also analysed by ICP-AE spectroscopy (BTPSF- $\mathrm{HNO}_{3}^{-2}$ ). Each analysis was done in triplicate and the results obtained had very high precision in the measurements obtained for each metal ion analysis with no deviations in some cases. The average of the three repeated measurements was taken. The metal ion concentrations measured using atomic absorption spectroscopy (AAS) gave positive results only for $\mathrm{Zn}$ and $\mathrm{Al}$, each in ppm scale. The concentrations of $\mathrm{Zn}, \mathrm{Cd}, \mathrm{Cu}, \mathrm{Ni}, \mathrm{Co}, \mathrm{Pb}, \mathrm{Mn}$ and $\mathrm{Cr}$ were in not detectable levels by the AAS. As such, all the measurements were done using ICP-AE spectroscopy.

\subsubsection{Dry-ashing}

$1.00 \mathrm{~g}$ of the sludge sample placed in a ceramic crucible was heated in a preheated muffle furnace at 200-250 ${ }^{\circ} \mathrm{C}$ for $30 \mathrm{~min}$, and then ashed for $4 \mathrm{~h}$ at $480^{\circ} \mathrm{C}$. Then, the sample was removed from the furnace and allowed to cool down to room temperature. $2.00 \mathrm{~mL}$ of $5 \mathrm{M} \mathrm{HNO}_{3}$ was added and evaporated to dryness on a sand bath. Next, the sample was placed in a cool furnace and heated to 400 ${ }^{\circ} \mathrm{C}$ for $15 \mathrm{~min}$, which was then allowed to cool down and moistened with four drops of distilled water. Next, 2.00 $\mathrm{mL}$ of concentrated $\mathrm{HCl}$ was added and the sample was evaporated to dryness, removed, and then $5.00 \mathrm{~mL}$ of $2 \mathrm{M}$ $\mathrm{HCl}$ was added and the tube was swirled. The solution was filtered through Whatman No. 42 filter paper and Millipore filter paper with pore size $<0.45 \mathrm{pm}$, and then transferred quantitatively to a $25.00 \mathrm{~mL}$ volumetric flask and adjusted the volume with distilled water and homogenized by shaking.

\subsubsection{Extraction of metal ions using glacial acetic acid and} analysis

The solid sludge generated after removing most of the water in BTPS is termed filter cake, which was analysed for $\mathrm{Zn}, \mathrm{Al}, \mathrm{Cd}, \mathrm{Cu}, \mathrm{Ni}, \mathrm{Co}, \mathrm{Pb}, \mathrm{Mn}$ and $\mathrm{Cr}$ using ICP-AE Spectroscopy. The filter cake of dry sludge $(50.0 \mathrm{~g})$ is completely combusted, at $600{ }^{\circ} \mathrm{C}$, for $12 \mathrm{~h}$, to remove any carbon as carbon dioxide and hydrogen as water vapour to obtain an ash coloured solid mass (10.0 g) which was powdered and homogenized. $2.00 \mathrm{~g}$ of this solid was reacted with $100 \mathrm{~mL}$ of glacial acetic acid, by stirring for $2 \mathrm{~h}$, in order to dissolve any metal ion present in the powder. The solution thus prepared resembles the composition of the original sludge suspension with identical TDS and is termed BTPSF-HAc-1. The concentrations were calculated using calibration plot with respect to each and every metal ion analysed which was constructed using standard solutions provided by the manufacturer. The residue was dried and re-analysed for $\mathrm{Zn}, \mathrm{Al}, \mathrm{Cd}$, $\mathrm{Cu}, \mathrm{Ni}, \mathrm{Co}, \mathrm{Pb}, \mathrm{Mn}$ and $\mathrm{Cr}$ by repeating the above procedure for the solution it generated which is termed BTPSF-HAc- 2.

\subsubsection{AOAC Official Method 990.08}

$1.00 \mathrm{~g}$ test portion of well-mixed material was weighed to nearest $0.01 \mathrm{~g}$ (wet weight basis), and transferred to $250.0 \mathrm{~mL}$ beaker. To express results on dry weight basis, another portion of material was dried to constant weight to determine wet/dry weight ratio, but did not digest and analyse this portion because the composition of the dried portion could be different to that of TDS of wet component possibly due to evaporative losses. $10.00 \mathrm{~mL} \mathrm{50 \%} \mathrm{HNO}_{3}$ was added to undried test portion and mixed well. The beaker was covered with watch glass, heated to $95^{\circ} \mathrm{C}$, and allowed to digest at room temperature. $5.00 \mathrm{~mL}$ concentrated $\mathrm{HNO}_{3}$ was then added and the watch glass was replaced, and the solution was refluxed for another $30 \mathrm{~min}$ at $95^{\circ} \mathrm{C}$. Finally, the solution was evaporated to ca. $5 \mathrm{~mL}$ without letting any section of the bottom of the beaker to go dry (ribbed watch glass allows evaporation and protects beaker contents from dust.) Solution was then allowed cool down to room temperature, $2 \mathrm{~mL}$ of water and $3 \mathrm{~mL} 30 \%$ $\mathrm{H}_{2} \mathrm{O}_{2}$ were added and the beaker was covered with watch glass, and heated slowly to initiate peroxide reaction. Heating was continued until effervescence subsides and the solution was allowed to cool, and $7.00 \mathrm{~mL} 30 \% \mathrm{H}_{2} \mathrm{O}_{2}$ in 1.00 $\mathrm{mL}$ portions were added while heating. The solution was allowed to cool down to room temperature and $5.00 \mathrm{~mL}$ concentrated $\mathrm{HCl}$, and $10.00 \mathrm{~mL}$ water were added and covered with watch glass, and the solution was refluxed for further $15 \mathrm{~min}$ without boiling. The solution was allowed to cool to room temperature, diluted to $100.0 \mathrm{~mL}$ with water, and mixed well. Any particulate matter in the digested suspension was removed by filtration.

\subsubsection{Digestion of vegetable samples for heavy metal deter- mination}

The vegetable samples were weighed to determine the fresh weight and dried in an oven, at $80^{\circ} \mathrm{C}$, for $72 \mathrm{~h}$ to deter- 
mine their dry weight. The dry samples were crushed in a mortar and the resulting powder was digested by weighing $0.50 \mathrm{~g}$ of oven-dried ground and sieve $(<1 \mathrm{~mm})$ into an acid washed porcelain crucible and placed in a muffle furnace for four hours at $500{ }^{\circ} \mathrm{C}$. The crucibles were removed from the furnace and cooled. $10.00 \mathrm{~mL}$ of $6 \mathrm{M} \mathrm{HCl}$ was added. The crucibles were covered and heated on a steam bath for 15 minutes. Another $1.00 \mathrm{~mL}$ of $\mathrm{HNO}_{3}$ was added and evaporated to dryness by continuous heating for one hour to dehydrate silica and completely digest organic compounds. Finally, $5.00 \mathrm{ml}$ of $6 \mathrm{M} \mathrm{HCl}$ and $10 \mathrm{~mL}$ of water were added and the mixture was heated on a steam bath to complete dissolution. The mixture was cooled and filtered through a Whatman no. 541 filter paper into a $50.0 \mathrm{~mL}$ volumetric flask and made up to mark with distilled water.

\subsection{Preparation of Compost Fertilizers}

Two different trials were prepared by mixing in different ratios of the above raw materials as illustrated in Table 1. Biological Sludge was obtained from Natural rubber glove industry in Sri Lanka.

TABLE 1: Proportions of raw materials mixed in two trials for the preparation of organic fertilizer.

\begin{tabular}{c|ccc} 
Raw Material & \multicolumn{2}{c}{ Mass/kg } \\
\hline Biological Sludge & Compost 1 & Compost 2 \\
\hline Old leaves & 35 & 120 \\
\hline Saw dust & 80 & 25 \\
\hline Chicken manure & 0 & 0 \\
\hline Goat manure & 30 & 15 \\
\hline Cow dung & 30 & 10 \\
\hline
\end{tabular}

\subsubsection{Preparation of Compost Piles}

Five feet thick dry corn stalk was first laid on precleaned ground. A mixture of crushed dry leaves and dry manure was then piled up to $8-10$ inches of thickness on top of the corn stalk. Then, de-watered sludge, which was dispersed in a minimum amount of water, was poured on top of the layer up to 2-3 inch thickness. A layer of green leaves was then laid on top of this layer. $300 \mathrm{~g}$ of old compost and $100 \mathrm{~g}$ of urea were added to the top layer.

All the steps described above was repeated several times until the bed thickness of about 4.5 feet. The final bed prepared by completing all the steps was covered with a polythene sheet. Temperature and moisture were monitored in the daily basis. Entire bed was turned once every week in order to supply sufficient amount of air to the bed. A graphical representation of all the steps involved is shown in Figure 1. Nutritional value of the Biological Treatment Plant Waste of natural rubber and the compost 1 and 2 was analysed together with its heavy metal content, $\mathrm{Zn}$ and $\mathrm{Al}$.

\subsection{Application of the Compost Fertilizer in Agriculture}

\subsubsection{Fields Selection of the sample depth}

The depth of sampling from surface sediment depends upon the purpose of the investigation. For the precise examination of soil contaminated with heavy metals, samples were collected from the top surface of the soil at depth of 0-6 inch level and also another set of from the deeper 6-24 inch level. Numbers of control and analyte soil samples were collected from the different plantations are given below in Table 2 .

\subsubsection{Control and Analyte Soil Sampling}

In soil sampling, the surface of the sample point was first cleaned with a hoe. Then, using a crown bar, small pit

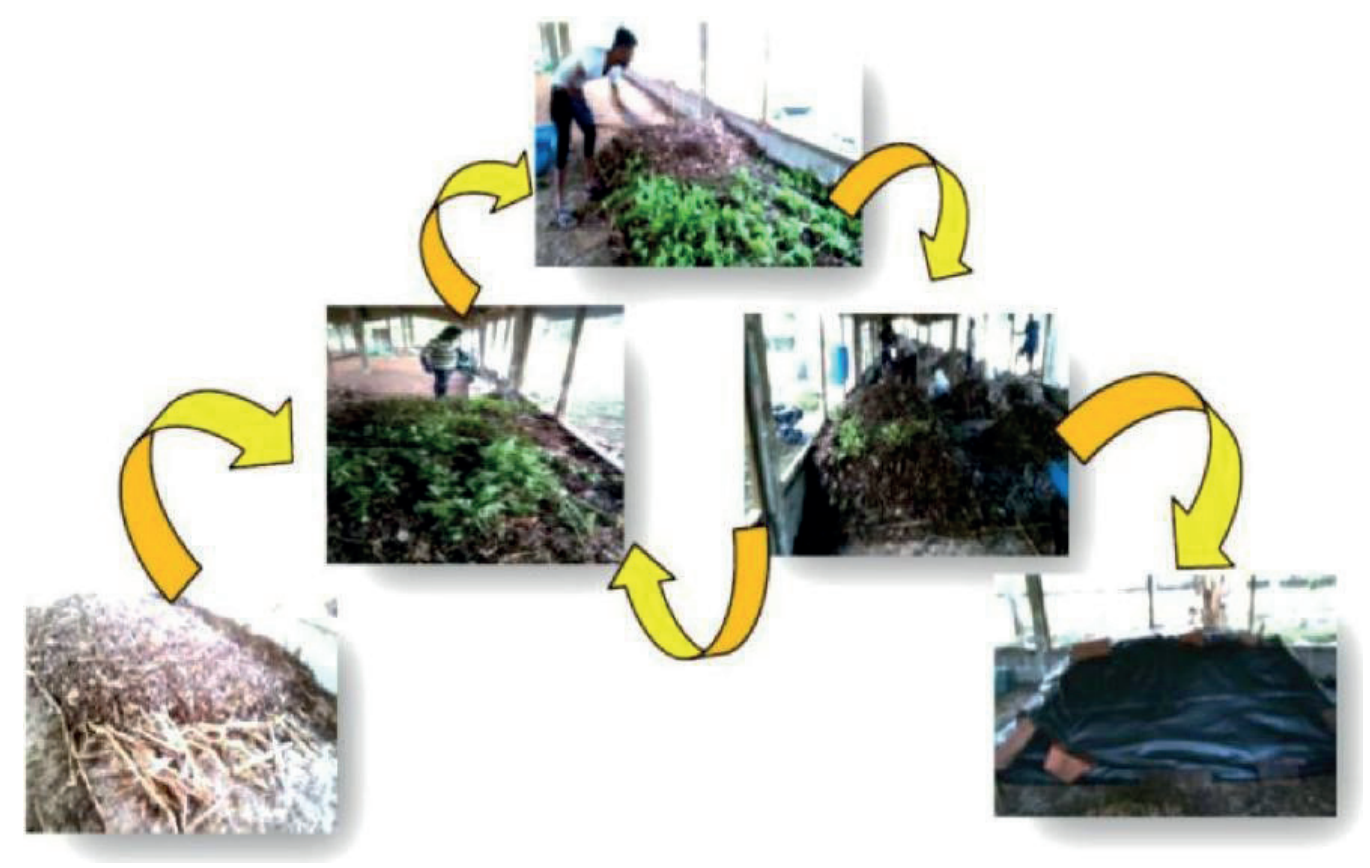

FIGURE 1: Graphical representation of the use of Biological Treatment Plant Sludge generated at wastewater treatment plants of natural rubber glove dipping industries together with other raw materials for the production of organic fertilizer. 
TABLE 2: Proportions of raw materials mixed in two trials for the preparation of organic fertilizer.

\begin{tabular}{l|cccccc}
\hline Location & No. of Control samples & No. of Sample Analyte samples \\
\hline Bitter gourd/ Ladies Fingers Plantation & 02 & 02 \\
\hline Snake gourd Plantation & 02 & 06 \\
\hline Papaya Plantation & 30 & 06 \\
\hline Chicken manure & 30 & 15 \\
\hline Goat manure & 30 & 10 \\
\hline Cow dung & & 0 \\
\hline
\end{tabular}

was created up to the depth of the pit of 0-6 inch and the soil part was obtained from the pit was thoroughly mixed. From the homogenized sample, $250.0 \mathrm{~g}$ of soil sample was collected for the analysis. The pit was then dug to its depth from 6" to 24 " and $250.0 \mathrm{~g}$ of soil sample from the soil collected was also obtained as before. These samples are labelled as control samples with the depths 0-6" and 6-24", respectively.

Control samples were collected from each of the plantation locations where the control sample points were selected as shown in Figure 2 (a). Each of the corners of the square of ...cm in length represent four adjacent plants cultivated in the field. They were watered to a circle of 12 " radius every day which was designated as wet-area. Whenever fertilizer was applied it was done within this circle. The control sampling points were selected from the ... radius of circle around point that crosses the two diagonals of the square as shown in Figure 2(a). This is to ensure that there is no direct application of the fertilizer to the control points and that leakage from the adjacent sample points is also minimal since the distance between the nearest points of the circle around the plant to which water is applied daily is much higher than the radius of the circle. Measurements were done in dry season to avoid the errors due to contamination by flushing the components in the applied fertilizer with rain water to the control point. The analyte sampling points were selected from 4- 5" distance from the cultivated plant for the sampling at 0-6" and 6"-24" depth levels as shown in Figure 2(b).

(a)

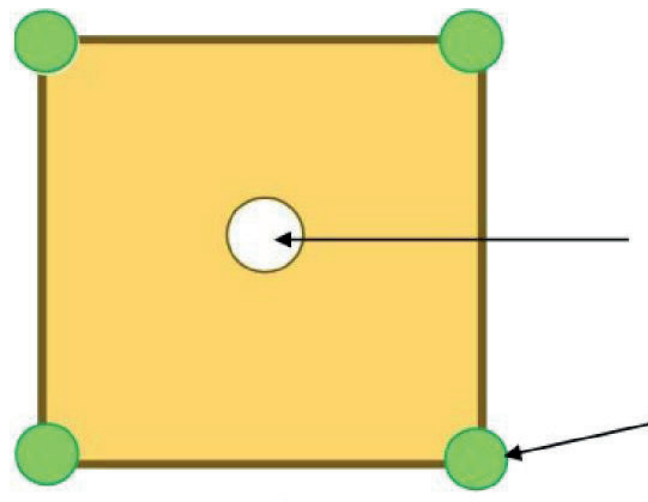

\section{Control Sample point}

Cultivated Plants

(b)

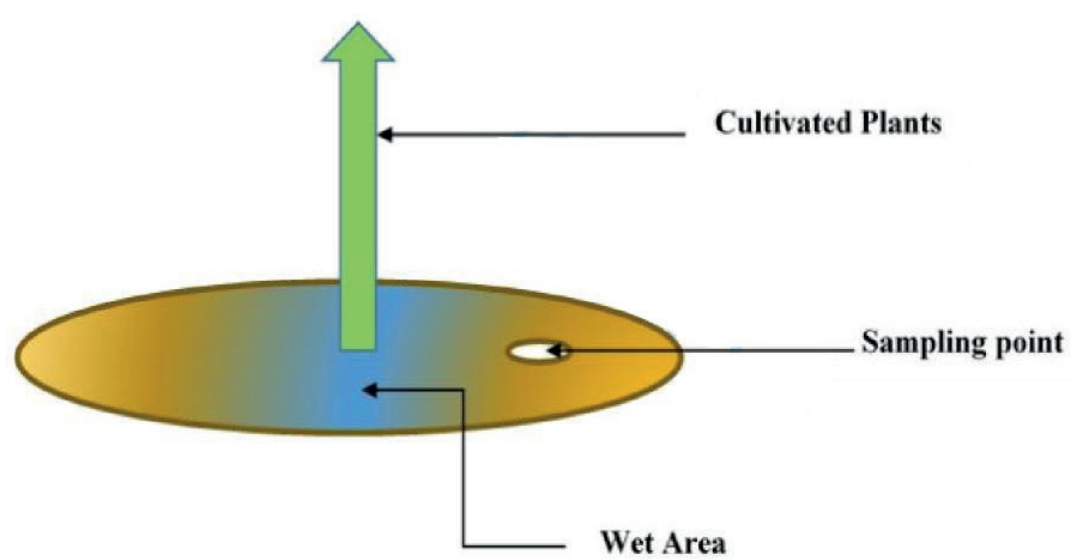

FIGURE 2: Geometric representation of (a) Control (b) Analyte Soil Sampling Points. 


\section{RESULTS AND DISCUSSION}

Figure 3 gives the composition of the BTPS of NRPP of SL. Results obtained clearly indicate that the amounts detected depend very strongly on the method used for the extraction of the species although the same analytical method is used in the analysis (ICP-AE). During dry-ashing, most of the metal ions become their oxides while volatile components are susceptible to lose by evaporation (Jorhem, 2019). Some of the species may be present within the protein 3-D structures of dead bacteria. Therefore, acid digestion may not completely extract some of the components. It is also possible that the extraction by acid digestion may depend on the digestion time if the extraction to acid solution is slow (Karasov and Douglas, 2013). Therefore, comparison of results obtained by different methods seems a difficult task. Group 12 elements Zn, Cd and Hg are generally known as volatile metals.

However, since $\mathrm{Zn}$ and $\mathrm{Al}$ are present mainly as their ox- ides and ZDBC is also converted to $\mathrm{ZnO}$ during dry-ashing. Both $\mathrm{ZnO}$ and $\mathrm{Al}_{2} \mathrm{O}_{3}$ are highly soluble and react in $\mathrm{HNO}_{3}$ giving respective ions. It could, therefore, be reliably assume that $\mathrm{Zn}$ and $\mathrm{Al}$ are completely extracted by dry-ashing followed by $\mathrm{HNO}_{3}$ extraction. Cadmium is contaminated to the NRPP of SL from the pigments used. Generally, there are three types of cadmium pigments: Cadmium yellow which is cadmium sulphide (CdS) [C.I. Pigment Yellow 37], Cadmium sulphoselenide is a solid solution of CdS and CdSe, which depending on the S/Se ratio, different colours can be obtained [C.I. Pigment Orange 20 or C.I. Pigment Red 108]. A green pigment is obtained by mixing Cadmium yellow is sometimes mixed with viridian to give a bright, pale green mixture called cadmium green. In dry-ashing volatile organic cadmium compounds are formed and are escaped. As such, dry-ashing is not a suitable method to determine cadmium whereas wet digestion with nitric acid gives a reliable measure of cadmium while acetic acid di-

(a)

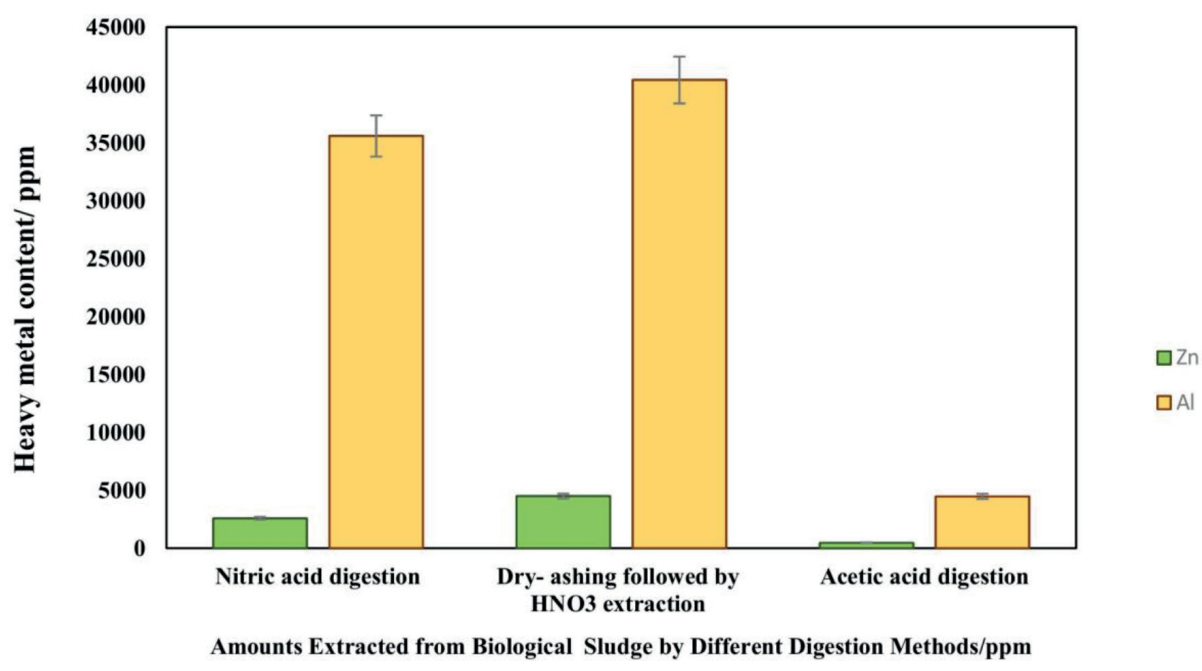

(b)

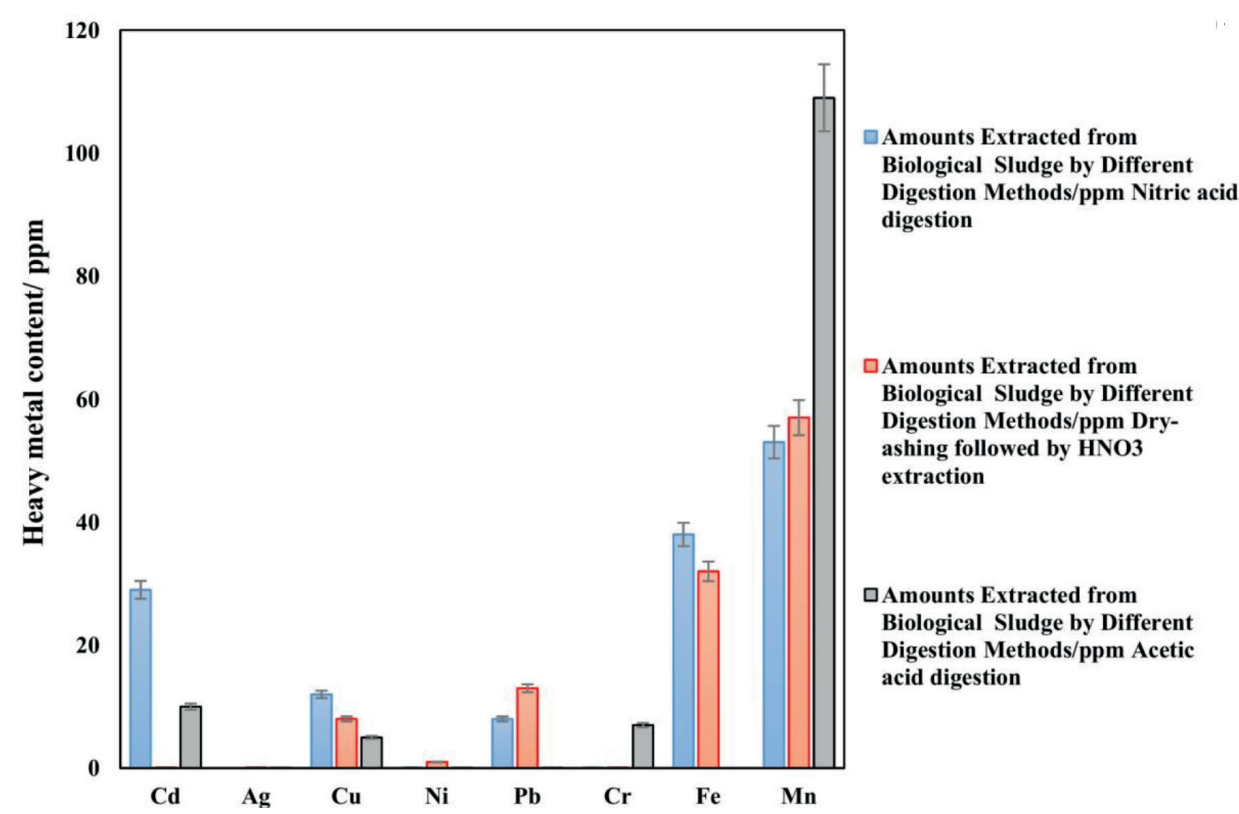

FIGURE 3: Concentrations in ppm of the metal ions analyzed in the Biological Sludge using Nitric acid digestion, Dry ashing followed by Nitric acid digestion and Acetic acid digestion methods (a) for $\mathrm{Cd}, \mathrm{Ag}, \mathrm{Cu}, \mathrm{Ni}, \mathrm{Pb}, \mathrm{Cr}, \mathrm{Fe}$ and $\mathrm{Mn}$ (b) for $\mathrm{Zn}$ and $\mathrm{Al}$. 
gestion tend to give lower value than that from nitric acid digestion. Although cadmium acetate is highly soluble in water, it exists in solid state as a coordination polymer where cadmium ions are coordinated by donated lone pairs of acetate ions. If such a polymer is present in the mixture of the sludge, its extraction to water could be slow whereas in nitric acid digestion cadmium exists purely as $\mathrm{Cd}^{2+}$ ions which are readily extracted. Extraction of all other species except manganese is preferred by dry-ashing. Interestingly, highest extraction of $\mathrm{Mn}$ is observed with acetic acid digestion. Mn too is introduced to the effluent and consequently to the sludge from pigments used: Manganese violet which is $\mathrm{NH}_{4} \mathrm{Mn}$ $\mathrm{P}_{2} \mathrm{O}_{7}$ (PV16) (Manganicammonium pyrophosphate). These pyrophosphate compounds are more soluble in acetic acid than in nitric acid giving manganous acetate which is highly soluble in water. Besides any remaining phosphate is a nutrient to a fertilizer (Razaq et al., 2017) which is an added advantage of using acetic acid. Any remaining manganeous that has not been extracted would exist as manganeous acetate which is also Mn supplement to fertilizer.

It is important to realize that composition of the industrial wastewater can be highly variable and depend on the amounts of materials used and hence contaminated to water in a given production time. It is critically important in glove industries since different types of gloves with different properties such as colour, texture, feel, abrasive resistance etc. are produced in the same factory at different times, depending upon the demand. As such, it is important to analyse water quality parameters of effluent waters as a function of time at least when different batches of gloves are produced using colorants (pigments) in different amounts. As such, chemical analysis of the BTPS was outsourced to SGS Lanka Ltd. which is an accredited analytical company in Sri Lanka. Samples collected on 27/07
$2015,24 / 05 / 2016$ and $11 / 10 / 2017$ were analysed in this way and the results are collected in Table 3 . Although the composition is different in different samples, dangerous heavy metals are either in such low quantities not detectable by the method used or below the maximum allowable limits. As such, it is desirable to analyse the sludge that is used to manufacture organic compost fertilizer without relying on results of previous analyses.

In order to obtain reliable results, we searched for an improved method that can be used to extract metal ions present in industrial sludge samples. We then found that AOAC Official Method 990.08 is the most suitable method for digesting aqueous samples containing low TDS of 2\% $\mathrm{w} / \mathrm{w}$. As such, in our further work, we used this method for extraction of metal ions in BTPS of NRPP of Sri Lanka [Official Methods of Analysis of AOAC International, 16th Edition, 4th Revision, 1998 Volume I].

Suitability of NRPP Sludge as a raw material to produce organic fertilizer depends on its quality which includes nutritional value and toxic components. As a general rule, higher the nutritional value and lower the toxic components, better is the raw material. As such, we have compared the heavy metal content of the sludge with maximum allowable limits of heavy metals in raw materials that are used to manufacture organic fertilizer for application to vegetation soils according to the SLS 1236:2003 Guidelines which are given in the last columns of Table 4.

SLS 1236:2003 Guidelines do not give maximum allowable limits for aluminium though aluminium is non-essential for plant growth and available or soluble aluminium can be toxic to plants, whereas other forms of aluminium such as aluminosilicates and precipitates, or forms of aluminium bound up in ligands are decidedly not phytotoxic. In this sludge,aluminium exists in essentially insoluble

TABLE 3: Proportions of raw materials mixed in two trials for the preparation of organic fertilizer.

\begin{tabular}{|c|c|c|c|c|}
\hline Heavy Metal & $\begin{array}{c}\text { Max. Allow- } \\
\text { able Limit ppm }\end{array}$ & $\begin{array}{c}\text { Quantity in ppm } \\
\text { on } 27 / 07 / \\
2015\end{array}$ & $\begin{array}{c}\text { Quantity in ppm } \\
\text { on } 24 / 05 / \\
2016\end{array}$ & $\begin{array}{c}\text { Quantity in } \\
\text { ppm on } 11 / 10 / \\
2017\end{array}$ \\
\hline $\mathrm{Zn}$ & 1000 & 199 & 1617 & 1020 \\
\hline $\mathrm{Cu}$ & 400 & $\mathrm{u}$ & 23 & $\mathrm{u}$ \\
\hline $\mathrm{Cd}$ & 10 & 4.9 & $\mathrm{u}$ & $\mathrm{u}$ \\
\hline $\mathrm{Pb}$ & 250 & $\mathrm{u}$ & $\mathrm{u}$ & 45 \\
\hline $\mathrm{Hg}$ & 02 & $\mathrm{u}$ & $\mathrm{u}$ & 0.35 \\
\hline $\mathrm{Ni}$ & 100 & $\mathrm{u}$ & 5.9 & 5.9 \\
\hline $\mathrm{Cr}$ & 1000 & u & 21 & 9 \\
\hline
\end{tabular}

TABLE 4: Nutritional value of Biological Treatment Plant Sludge collected on 29/07/2015.

\begin{tabular}{|c|c|c|}
\hline Parameter & Protocol & Mass \% \\
\hline Organic C & Ref: Soil Chemical Analysis by M.I. Jackson & 30.3 \\
\hline $\mathrm{N}$ as total $\mathrm{N}$ & SLS 645:PART 2, 1984 & 5.2 \\
\hline $\mathrm{P}$ as $\mathrm{P} 205$ & SLS 645:PART 5, 1985 & 3.5 \\
\hline $\mathrm{K}$ as $\mathrm{K} 2 \mathrm{O}$ & AOAC 3.016 & 0.1 \\
\hline $\mathrm{Mg}$ as $\mathrm{MgO}$ & Flame AAS & 0.08 \\
\hline $\mathrm{Ca}$ as $\mathrm{CaO}$ & Flame AAS & 7.1 \\
\hline Sand\% & AOAC 3.005 & 2.6 \\
\hline
\end{tabular}


forms in water around neutral $\mathrm{pH}$ values that are present in natural environments and hence excess aluminium would not contribute to drastic drawback. Cadmium is present at the upper limit though other heavy metals are either absent or present well below maximum allowable limits. Even then, there is a possibility to accumulate these toxic species in the soil or biota due to repeated application of the fertilizer to the soil of the vegetation (Aktar et al., 2009).

Nutritional value of the sludge which was collected at different times was also analysed by outsourcing to Industrial Technology Institute (ITI) of Sri Lanka which is an accredited laboratory for analyses. Results show nutrients such as $\mathrm{P}, \mathrm{K}, \mathrm{Mg}$ and $\mathrm{Ca}$ in acceptable ranges but with much lower $\mathrm{C}: \mathrm{N}$ ratio of 6:1. Data obtained on the sample collected on 29/07 2015 are given in Table 4.

We believe that such low $\mathrm{C}: \mathrm{N}$ ratio (i.e., high $\mathrm{N}$ content relative to carbon content) obtained may not be accurate and may depend on many factors such as different protocols used in $\mathrm{C}$ and $\mathrm{N}$ analysis and insufficient digestion of the sample in the carbon analysis. Repeated analyses done during 2015- mid 2017 gave similar results. It has been reported that for best performance, the compost pile, or the composting microorganisms, require the correct proportion of carbon for energy and nitrogen for protein production. (Pan et al., 2011) Fastest way to produce fertile, sweet-smelling compost is to maintain a $\mathrm{C}: \mathrm{N}$ ratio between 25 to 30 parts carbon to 1 part nitrogen, or 25-30:1. If the C:N ratio is too high (excess carbon), decomposition slows down and if the $\mathrm{C}: \mathrm{N}$ ratio is too low (excess nitrogen) the

TABLE 5: Metal ion concentrations in the Biological Treatment Plant Sludge collected on 27/06/2017, which was determined following AOAC Official Method.

\begin{tabular}{c|cc} 
Metal ion & Conc. (pp) & Conc. (ppm) \\
\hline $\mathrm{Al}$ & $1,880,000$ & 1880 \\
\hline $\mathrm{Zn}$ & 987,000 & 987 \\
\hline $\mathrm{Cu}$ & 98 & 0.98 \\
\hline $\mathrm{Cd}$ & 90 & 0.90 \\
\hline $\mathrm{Pb}$ & 50 & 0.50 \\
\hline $\mathrm{Hg}$ & Not detected & Not detected \\
\hline $\mathrm{Ni}$ & 5,700 & 5.7 \\
$\mathrm{Cr}$ & 9,000 & 9.0 \\
\hline
\end{tabular}

compost pile will be stinky (Manzoni et al., 2008). As such, searching for a reliable method for nutritional analysis became essential. Having observed the need to analyse the raw materials used in preparation of organic compost fertilizer in each and every batch manufactured, and to use most appropriate analytical method, we used AOAC Official Method 990.08 for metal ion extraction of the batch of sludge collected on 27/07/2017 and improved SLS 1246:2003 protocol for nutrient analysis. Results obtained are given in Tables 5 and 6, respectively.

As can be seen from the data given in Table 5, maximum extraction is achieved when AOAC Official Method was used. It is important to note, however, that the composition of an industrial sample is highly variable and may depend on the amounts of raw materials, dyes, pigments etc. used in a given day. However, since AOAC Method seems to be the most reliable methods, further analyses were done by extracting according to this method.

These results give an appreciable C:N ratio of 18.9:1 this is within the most suitable range required for composting. However, even if heavy metals are present in the sludge at much lower levels than maximum allowable limits the compost should not contain even those amounts of heavy metals. As such, when using BTP sludge as a raw material, the levels of heavy metals, $\mathrm{Zn}$ and $\mathrm{Al}$ should be lowered as much as possible. This can be done by two ways: (i) by diluting the heavy metal contents using other natural raw materials which have much lower or no heavy metal contents and mixing the raw materials in required proportions to pile up for composting in such a way to balance the $\mathrm{C}: \mathrm{N}$ ratio also and (ii) by removing heavy metals, $\mathrm{Zn}$ and $\mathrm{Al}$ from the effluent stream at an earlier stage before directing to the biological treatment plant. We made use both strategies and in (i) BTP sludge and other raw materials such as cow dung, goat manure, chicken manure, dry plant leaves etc. were mixed in required proportions for piling up to make compost fertilizer. In (ii), we have designed and adapted an additional treatment plant in the middle of the flow process with the sequence Rubber Particle Trap - Drape - Precipitation Tank - Biological Treatment Plant. In the precipitation tank we use right amounts of $\mathrm{K}_{2} \mathrm{~S}$ so that heavy metals, $\mathrm{Al}$ and $\mathrm{Zn}$ ions precipitate as their respective sulphides while $\mathrm{K}^{+}$introduced mixes with the BTP sludge which also contributes to the nutritional value of the sludge. We have analysed the sludge generated this way also and used for compost-

TABLE 6: Analysis of Nutritional value and other components of Biological Treatment Plant Sludge collected on 17/05/2017 (Measured at SGS).

\begin{tabular}{|c|c|c|}
\hline Parameter & Protocol & Mass\% \\
\hline Organic C & ISO 14235:1998 & 5.6 \\
\hline $\mathrm{N}$ as total $\mathrm{N}$ & SLS 645:PART 1 & 0.3 \\
\hline $\mathrm{P}$ as $\mathrm{P} 205$ & SLS 645:PART 5 & 2.3 \\
\hline $\mathrm{K}$ as $\mathrm{K} 2 \mathrm{O}$ & SLS 645:PART 4 & 253 ppm \\
\hline $\mathrm{Mg}$ as $\mathrm{MgO}$ & SLS 645:PART 6 & $\mathrm{u}$ \\
\hline $\mathrm{Ca}$ as $\mathrm{CaO}$ & SLS 645:PART 6 & 5.0 \\
\hline $\mathrm{Al}$ & EPA 3051:2007 & 0.86 \\
\hline $\mathrm{Cr}$ & 9,000 & 9.0 \\
\hline
\end{tabular}


TABLE 7: Heavy metal, $\mathrm{Zn}$ and $\mathrm{Al}$ and nutritional values of compost formulations prepared. U-undetected.

\begin{tabular}{c|c|c}
\hline Component & Compost 1 & Compost 2 \\
\hline C\% & 4.8 & 20.7 \\
\hline \% & 0.4 & 1.3 \\
\hline \% & 0.7 & 2.9 \\
\hline K\% & 0.5 & 0.8 \\
\hline$M g$ & 1.2 & $\mathrm{u}$ \\
\hline $\mathrm{Ca} \%$ & 2.8 & $\mathrm{u}$ \\
\hline $\mathrm{C}: \mathrm{N} \mathrm{Ratio}$ & 12 & 16 \\
\hline $\mathrm{Cr}(\mathrm{ppm})$ & 17 & $\mathrm{u}$ \\
\hline $\mathrm{Cu} / \mathrm{ppm}$ & 35 & $\mathrm{u}$ \\
\hline $\mathrm{Pb}(\mathrm{ppm})$ & $\mathrm{u}$ & $\mathrm{u}$ \\
\hline $\mathrm{Hg}(\mathrm{ppm})$ & $\mathrm{u}$ & $\mathrm{u}$ \\
\hline $\mathrm{Ni}(\mathrm{ppm})$ & $\mathrm{u}$ & $\mathrm{u}$ \\
\hline $\mathrm{Zn}(\mathrm{ppm})$ & 334 & $\mathrm{u}$ \\
\hline $\mathrm{Cd}(\mathrm{ppm})$ & $\mathrm{u}$ & $\mathrm{u}$ \\
\hline
\end{tabular}

ing. However, we will reveal this study in a subsequent publication. Here we describe the Method (i) where the BTP sludge was diluted with other raw materials in order to prepare compost fertilizer by taking $\mathrm{C}: \mathrm{N}$ ratio as the guide. The $\mathrm{C}: \mathrm{N}$ ratios of the raw materials collected on $24 / 07 / 2017$ which were used to make compost formulations were measured following SLS 1247: Appendix F: 2003 protocol (at SGS Ltd.). The C:N ratios obtained for sludge, cow dung, chicken manure, goat manure and dry plant leaves are 19, 22, 10, 23 and 61, respectively. They were used in the proportions given in Table 1 and the resulted compost formulations were also analysed for their heavy metal, $\mathrm{Zn}$ and $\mathrm{Al}$ contents and nutritional values. Results obtained are depicted in Table 7.

Required C:N ratio for organic compost fertilizer formulations lies between 10 and 25 and hence both formulations have the right $\mathrm{C}: \mathrm{N}$ ratios. $\mathrm{C}: \mathrm{N}$ ratio of urea is 2.3 and is a highly $\mathrm{N}$-rich fertilizer and a $\mathrm{C}: \mathrm{N}$ ratios close to 10 are highly appropriate for $\mathrm{N}$-rich organic compost fertilizers. Heavy metal concentrations in each level of samples collected from 0-6 and 6-24 inch levels of soils in the snake guard and papaya plantations as detailed in the experimental section are depicted in Figure 4.

As shown in the data, all of the components in both formulations are well below the maximum allowable limits imposed by SLS Standards for Compost fertilizers. As such, this dilution method to utilize otherwise problematic BTP waste generated in large tonnage quantities in NRGD Industries of Sri Lanka is not only a convenient way of its disposal but also a useful way to convert it to highly valuable product. We have also analysed the heavy metal contents of papaya fruit grown using prepared compost fertilizer, home grown without adding any fertilizer and those bought from open market in the Western Province of Sri Lanka and the data are given in Figure 5.

Interestingly, there is hardly any difference in heavy metal concentrations of different types of papaya samples studied. One important point is that all of them had very low levels of heavy metals which are well below the maximum allowable limits in vegetables and fruits that are imposed by Joint FAO/WHO Food standards.

\subsection{The Codex maximum level (ML)}

The product as it should be analysed and to which the ML applies, should be clearly defined. In general, MLs are set on primary products. MLs should in general preferably be expressed as a level of the contaminant related to the product as it is, on a fresh weight basis. In some cases, however, there may be valid arguments to prefer expression on a dry weight basis (this might be in particular the case for contaminants in feed) or on a fat weight basis (this might be in particular the case for fat soluble contaminants). Preferably the product should be defined as it moves in trade, with provisions where necessary for the removal of inedible parts that might interfere with the preparation and the analysis of the sample. The product definitions used by the CCPR and contained in the Classification of food and feed may serve as guidance on this subject; other product definitions should only be used for specified reasons. For contaminant purposes, however, analysis and consequently MLs should preferably be on the basis of the edible part of the product.

\section{CONCLUSIONS}

In this publication, we have shown, for the first time, an economical way of managing the waste water biological treatment plant sludge of natural rubber glove dipping industries in Sri Lanka. The sludge was converted to a valuable organic fertilizer which was applied for vegetable and fruit plantations. Compositions of the sludge and other raw materials used were carefully analysed by developing the most appropriate protocol for metal ion extraction. The fertilizer thus manufactured has no significant amount of heavy metals but have excellent nutritional value. Soils to which fertilizer was applied, vegetable and plant parts of the vegetation fertilized by this fertilizer were analysed and found that their heavy metal contents are less than those available in the open market and are much less than maximum allowable limits. As such, this work shows a useful way of sludge management which is applicable in large industrial scale.

\section{REFERENCES}

Aktar, W., Sengupta, D., \&Chowdhury, A. (2009). Impact of pesticides use in agriculture: their benefits and hazards. Interdisciplinary Toxicology, 2(1), 1-12. doi:10.2478/v10102-009-0001-7

Albers, E., Johansson, E., Franzén, C., \& Larsson, C. (2011). Selective suppression of bacterial contaminants by process conditions during lignocellulose based yeast fermentations. Biotechnology For Biofuels, 4(1), 59. doi:10.1186/1754-6834-4-59

Blackley, D. (1997). Latex-dipping processes. Polymer Latices, 155228. doi:10.1007/978-94-011-5848-0_3

Cummins PM, e. (2019). lon-exchange chromatography: basic principles and application to the partial purification of soluble mammalian prolyloligopeptidase. - PubMed - NCBI . Ncbi.nlm.nih.gov. Retrieved 23 May 2019, from https://www.ncbi.nlm.nih.gov/pubmed/20978968 

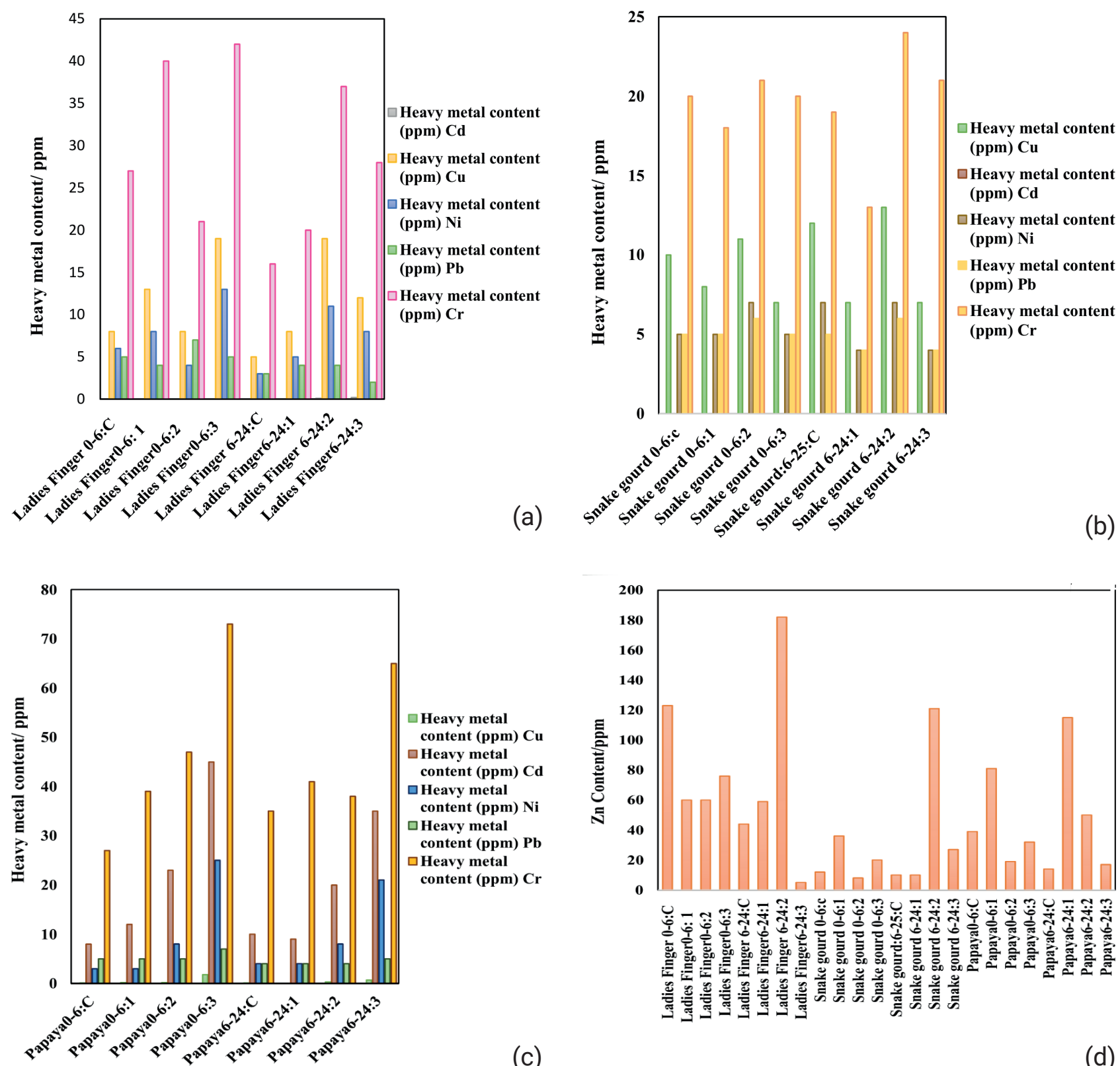

(c)

FIGURE 4: Heavy metal analytical data of soils in the vegetation extracted from control and several sample locations and depths. 0-6 and 6-24 indicate depth profiles. 1, 2 and 3 are randomly selected three sample locations inthevegetation. Different vegetable and fruit plantations used together with the depths from which soils were taken are indicated in the $x$-axis of the figures (a), (b), (c) and (d) whereas $y$-axis represents the concentrations in ppm of different types of heavy metals in (a) - (c) extracted from soils taken from different plantations at different depths and (d) the same for zinc.

Devaraj, V., Nur, F., Dayang, A., Nor, H., \&Zairossani, M. (2017). Utilization of Waste from Natural Rubber Glove Manufacturing Line. ASEAN Journal On Science And Technology For Development, 32(2), 94. doi:10.29037/ajstd.61

Enders, A., Lehmann. (2019)Comparison of Wet-Digestion and Dry-Ashing Methods for Total Elemental Analysis of Biochar. Communications In Soil Science And Plant Analysis. Retrieved from https:// www.tandfonline.com/doi/full/10.1080/00103624.2012.656167

Franke-Whittle, I., \&Insam, H. (2012). Treatment alternatives of slaughterhouse wastes, and their effect on the inactivation of different pathogens: A review. Critical Reviews In Microbiology, 39(2), 139151. doi:10.3109/1040841x.2012.694410

Gorsuch, T. (1959). Radiochemical investigations on the recovery for analysis of trace elements in organic and biological materials. Report to the Analytical Methods Committee by the Society's First Analytical Chemistry Research Scholar. The Analyst, 84(996), 135. doi:10.1039/an9598400135
Hseu, Z., Chen, Z., Tsai, C., Tsui, C., Cheng, S., Liu, C., \& Lin, H. (2002). Water, Air, And Soil Pollution, 141(1/4), 189-205. doi:10.1023/a:1021302405128

Jara-Samaniego, J., Pérez-Murcia, M., Bustamante, M., Paredes, C., Pérez-Espinosa, A., \&Gavilanes-Terán, I. et al. (2017). Development of organic fertilizers from food market waste and urban gardening by composting in Ecuador. PLOS ONE, 12(7), e0181621. doi:10.1371/journal.pone.0181621

Jorhem, L. (2019). Determination of metals in foods by atomic absorption spectrometry after dry ashing: NMKL Collaborative Study PubMed - NCBI . Ncbi.nlm.nih.gov. Retrieved 23 May 2019, from https://www.ncbi.nlm.nih.gov/pubmed/11048861

Karasov, W.H., \& Douglas, A. (2013). Comparative Digestive Physiology. Comprehensive Physiology. doi:10.1002/cphy.c110054

Kerdtongmee, P., Pumdaung, C., \&Danworaphong, S. (2014). Quantifying Dry Rubber Content in Latex Solution Using an Ultrasonic Pulse. Measurement Science Review, 14(5), 252-256. doi:10.2478/ msr-2014-0034 
(a)

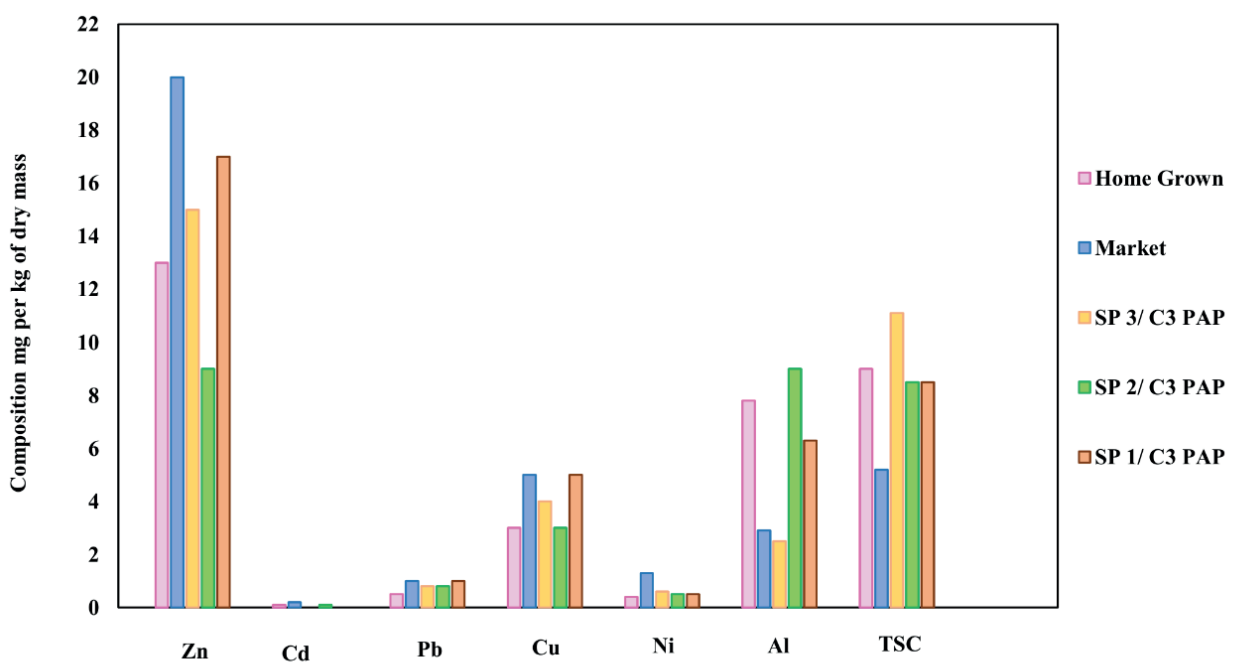

(b)

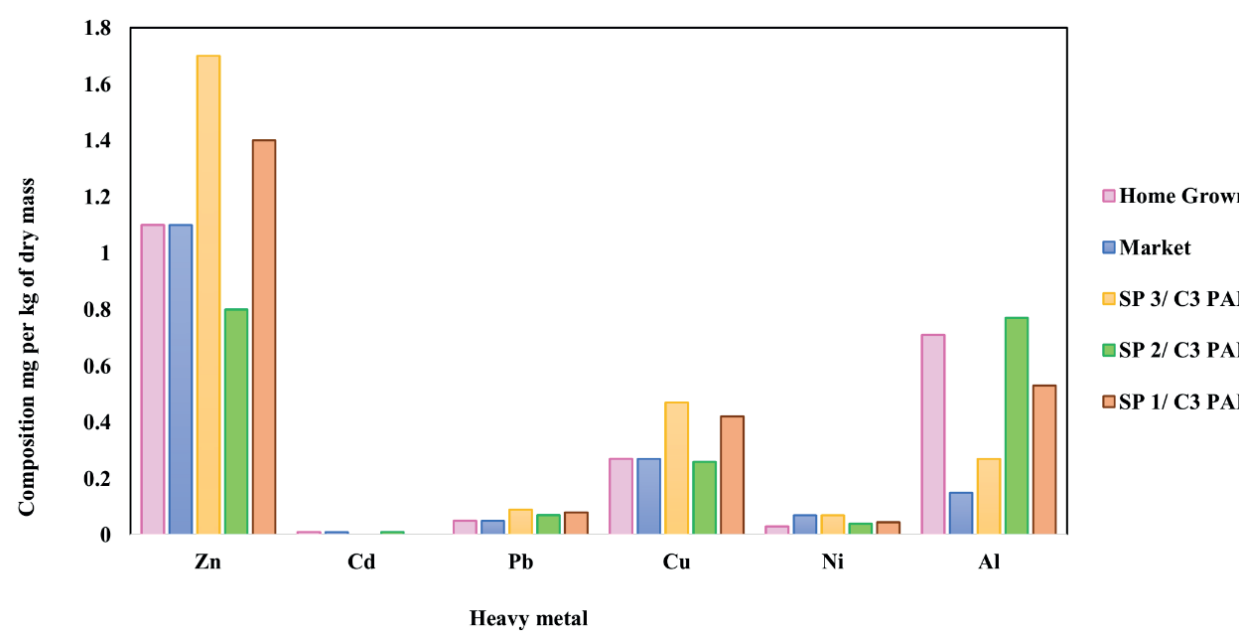

FIGURE 5: Heavy metal analysis of papaya grown by (a) applying prepared fertilizer (b) home grown without any added fertilizer and of those bought from open market for three sample points (SP-Sample Point, PAP- Papaya). Colour codes used for different samples are indicated within the figures.

LoPachin, R., Gavin, T., DeCaprio, A., \& Barber, D. (2011). Application of the Hard and Soft, Acids and Bases (HSAB) Theory to ToxicantTarget Interactions. Chemical Research In Toxicology, 25(2), 239251. doi: $10.1021 /$ tx2003257

Manzoni, S., Jackson, R., Trofymow, J., \&Porporato, A. (2008). The Global Stoichiometry of Litter Nitrogen Mineralization. Science, 321(5889), 684-686. doi:10.1126/science.1159792

Naqi, A., \& Jang, J. (2019). Recent Progress in Green Cement Technology Utilizing Low-Carbon Emission Fuels and Raw Materials: A Review. Sustainability, 11(2), 537. doi:10.3390/su11020537

Palanivell, P., Susilawati, K., Ahmed, O., \&Majid, N. (2013). Compost and Crude Humic Substances Produced from Selected Wastes and Their Effects onZeamaysL. Nutrient Uptake and Growth. The Scientific World Journal, 2013, 1-15. doi:10.1155/2013/276235

Pan, I., Dam, B., \&Sen, S. (2011). Composting of common organic wastes using microbial inoculants. 3 Biotech, 2(2), 127-134. doi:10.1007/s13205-011-0033-5

Pangarkar, B., Sane, M., \&Guddad, M. (2011). Reverse Osmosis and Membrane Distillation for Desalination of Groundwater: A Review. ISRN Materials Science, 2011, 1-9. doi:10.5402/2011/523124

Razaq, M., Zhang, P., Shen, H., \&Salahuddin. (2017). Influence of nitrogen and phosphorous on the growth and root morphology of Acer mono. PLOS ONE, 12(2), e0171321. doi:10.1371/journal. pone. 0171321
Rodushkin, I., Engstrm, E., Stenberg, A., \& Baxter, D. (2004). Determination of low-abundance elements at ultra-trace levels in urine and serum by inductively coupled plasma?sector field mass spectrometry. Analytical and Bioanalytical Chemistry, 380(2), 247-257. doi:10.1007/s00216-004-2742-7

Singh, R., Gautam, N., Mishra, A., \& Gupta, R. (2011). Heavy metals and living systems: An overview. Indian Journal Of Pharmacology, 43(3), 246. doi:10.4103/0253-7613.81505

Smith, SR. (2019). A critical review of the bioavailability and impacts of heavy metals in municipal solid waste composts compared to sewage sludge. - PubMed - NCBI . Ncbi.nlm.nih.gov. Retrieved 23 May 2019, from https://www.ncbi.nlm.nih.gov/pubmed/18691760

Turhanen, P., Vepsäläinen, J., \&Peräniemi, S. (2015). Advanced material and approach for metal ions removal from aqueous solutions. Scientific Reports, 5(1). doi:10.1038/srep08992

Wheal, M., Fowles, T., \& Palmer, L. (2011). A cost-effective acid digestion method using closed polypropylene tubes for inductively coupled plasma optical emission spectrometry (ICP-OES) analysis of plant essential elements. Analytical Methods, 3(12), 2854. doi:10.1039/c1ay05430a

Zheljazkov, V., Cantrell, C., Astatkie, T., \&Ebelhar, M. (2010). Peppermint Productivity and Oil Composition as a Function of Nitrogen, Growth Stage, and Harvest Time. Agronomy Journal. Retrieved from http://agris.fao.org/agris search/search.do?recordID $=$ US20130172827 